\title{
Fluoride therapy in the prevention of dental caries
}

\author{
Laura Strohmenger \\ From 70th Congress of the Italian Society of Pediatrics, Joint National Meeting SIP, SICuPP, SITIP \\ Palermo, Italy. 11-14 June 2014
}

The document "National Guidelines for the prevention and oral health promotion in childhood", 2013, is an act of address for those involved in the management of oral health and in particular to the pediatrician, because the figure of the pediatrician in the prevention of oral health is absolutely critical, as confirmed by the entire international literature in recent years.

Correct attitudes and behaviors adopted since childhood that will allow the child to protect his health.

The fluoride is the cornerstone of prevention of tooth decay and is required for all individuals.

Over the years, have been developed different means of administration of fluorine, each with different strengths, dosages and frequency of use [1-5].

Fluoride supplements should be prescribed by the pediatrician in cases of real difficulty for topical administration of fluoride through toothpaste or fluoride added as a method of in subjects at risk of tooth decay [6].

The decline of caries in our country it is highly likely also due to the pediatrician who, using the national guidelines, can inform parents and families induce the acquisition of preventive behaviors currently defined by scientific research [7].

To this end, again, the ministerial guidelines on the subject that were reviewed by a team of experts representative of the Italian research in this area.

\section{Published: 11 August 2014}

\section{References}

1. Marinho VC, Higgins JP, Logan S, Sheiham A: Fluoride gels for preventing dental caries in children and adolescents. Cochrane Database Syst Rev 2009, 2:CD002280.

2. Marinho VC, Higgins JP, Logan S, Sheiham A: Fluoride mouthrinses for preventing dental caries in children and adolescents. Cochrane Database Syst Rev 2009, 3:CD002284.

Correspondence: laura.strohmenger@unimi.it

Department Health's Science, H.San Paolo, Milan, Italy
3. Marinho VC, Higgins JP, Logan S, Sheiham A: Fluoride varnishes for preventing dental caries in children and adolescents. Cochrane Database Syst Rev 2009, 3:CD002279.

4. Marinho VC, Higgins JP, Sheiham A, Logan S: Combinations of topical fluoride (toothpastes, mouthrinses, gels, varnishes) versus single topical fluoride for preventing dental caries in children and adolescents. Cochrane Database Syst Rev 2009, 1:CD002781.

5. Marinho VC: Cochrane reviews of randomized trials of fluoride therapies for preventing dental caries. Eur Arch Paediatr Dent 2009, 10:183-91.

6. Twetman S: Caries prevention with fluoride toothpaste in children: an update. Eur Arch Paediatr Dent 2009, 10:162-7.

7. Twetman S: Prevention of early childhood caries (ECC)-review of literature published 1998-2007. Eur Arch Paediatr Dent 2008, 9:12-8.

doi:10.1186/1824-7288-40-S1-A71

Cite this article as: Strohmenger: Fluoride therapy in the prevention of dental caries. Italian Journal of Pediatrics 2014 40(Suppl 1):A71.
Submit your next manuscript to BioMed Central and take full advantage of:

- Convenient online submission

- Thorough peer review

- No space constraints or color figure charges

- Immediate publication on acceptance

- Inclusion in PubMed, CAS, Scopus and Google Scholar

- Research which is freely available for redistribution

Submit your manuscript at www.biomedcentral.com/submit
() Biomed Central
() Biomed Central

(c) 2014 Strohmenger; licensee BioMed Central Ltd. This is an Open Access article distributed under the terms of the Creative Commons Attribution License (http://creativecommons.org/licenses/by/4.0), which permits unrestricted use, distribution, and reproduction in any medium, provided the original work is properly cited. The Creative Commons Public Domain Dedication waiver (http://creativecommons.org/publicdomain/zero/1.0/) applies to the data made available in this article, unless otherwise stated. 